\title{
DNA Synthesis during Zoosporangial Differentiation in Allomyces arbuscula
}

\author{
By MUKTI OJHA* AND GILBERT TURIAN \\ Laboratoire de Microbiologie générale, Département de Biologie végétale, Université de \\ Genève, 1211 Genève 4, Switzerland
}

(Received 25 April 1980)

\begin{abstract}
The rate of DNA synthesis in Allomyces arbuscula during differentiation of zoosporangia depends on the stage of development. The first stage of cytoplasmic reorganization in the hyphal apex is accompanied by a rapid decrease in DNA synthesis. The appearance of septa and the development of young zoosporangia are paralleled by a renewal of DNA synthesis which then declines as the zoosporangia mature. The transfer of an actively growing mycelium to the induction medium results in a transient accumulation (up to $1 \mathrm{~h}$ post-transfer) of ATP in the cell, which then starts to diminish. Analysis of the pulse-labelled native DNA by neutral $\mathrm{CsCl}$ equilibrium density gradient centrifugation indicates that in these early stages, all the DNA is being synthesized at a uniform rate. The amount of rRNA cistrons varies with the developmental stage and, on reorganization of the hyphal apex, the synthesis of such genes is inhibited and subsequently stimulated as zoosporangia mature.
\end{abstract}

\section{INTRODUCTION}

Vegetative Allomyces is a coenocytic multinucleate filamentous cell which can differentiate apically either into zoosporangia (on sporophytic hyphae) or couples of male and female gametangia (on gametophytic hyphae). Although the differentiating hyphal tips are heavily populated with nuclei, active mitosis has been shown to occur during sexual differentiation following septation and isolation of these territories from the supporting hyphae (Hatch, 1935). For example, a nuclear count at the beginning and the end of gametangial differentiation showed a twofold increase in the number of male nuclei after septation (Hatch, 1935; Turian, 1957). This is suggestive of an active synthesis of DNA during apical differentiation.

In this paper we have examined a simpler system of apical differentiation - the zoosporangia - thus avoiding the more complex bisexual situation of gametophytic hyphae, and present our results on the synthesis of DNA and rRNA cistrons during zoosporangial morphogenesis. Furthermore, to understand the fluctuations in the uptake of precursor and labelling pattern of RNA and DNA, we measured the ATP levels during differentiation.

\section{METHODS}

Organism and culture conditions. Allomyces arbuscula strain Bali used throughout this study was maintained in YPSs (yeast extract/phosphate/soluble starch) slants (Emerson, 1941) as described earlier (Ojha \& Turian. 1971).

Inoculum. Young cultures in GCY (glucose/Casamino acids/yeast extract) medium (Turian, 1963) were filtered through Whatman filters, then washed and suspended in sterile DS (dilute salts) buffer (Machlis, 1953). Zoospore differentiation was complete in $5 \mathrm{~h}$. The zoospores discharged were collected by filtration through Whatman filters. A known amount of the spore suspension was diluted with twice its volume of GCY. Within 15 min the spores stopped swimming and were counted with a Thoma haemocy tometer.

Differentiation and DNA synthesis. GCY medium (21) was inoculated with zoospores at a final concentration of $1 \times 10^{4} \mathrm{ml}^{-1}$ and grown for $24 \mathrm{~h}$ at $25^{\circ} \mathrm{C}$ with forced aeration. The culture was filtered through nylon filters 
and the young plants were washed with 11 sterile DS buffer and suspended in $21 \mathrm{DS}$ buffer. At intervals, $200 \mathrm{ml}$ samples were taken and morphological differentiation was checked microscopically. The cells were harvested by filtration and total DNA and RNA were estimated according to Howell (1973). Protein was measured according to Lowry.

Pulse-labelling. The $200 \mathrm{ml}$ cell samples taken during differentiation were collected by filtration and quickly suspended in $20 \mathrm{ml}$ sterile DS buffer containing [ ${ }^{3} \mathrm{H}$ ]adenosine $\left(0.5 \mu \mathrm{Ci} \mathrm{ml}^{-1} ; 18.5 \mathrm{kBq} \mathrm{ml}^{-1}\right)$ and incubated at $25^{\circ} \mathrm{C}$ on a shaker for 20 to $30 \mathrm{~min}$. A $3 \mathrm{ml}$ sample was taken immediately, $1 \mathrm{ml}$ was added to $50 \mu \mathrm{l} 10 \mathrm{M}-\mathrm{NaOH}$ and $1 \mathrm{ml}$ to $100 \mu \mathrm{l} 100 \%$ trichloroacetic acid (TCA). The remaining $1 \mathrm{ml}$ was quickly filtered (Whatman GF/C filter), washed, dried and used to measure the total uptake of nucleoside by the cell. The remaining $17 \mathrm{ml} \mathrm{sample}$ was quickly filtered, frozen and used for ATP extraction. The $1 \mathrm{ml} \mathrm{sample} \mathrm{in} \mathrm{TCA} \mathrm{(final} \mathrm{concentration} 10 \%$, w/v) was chilled for at least $30 \mathrm{~min}$, then filtered (Whatman GF/C), washed three times with $5 \mathrm{ml}$ portions of $5 \%$ cold TCA containing $1 \%$ sodium pyrophosphate and three times with cold $95 \%$ ethanol; it was then dried and counted for total acid-precipitable radioactivity. The sample in $\mathrm{NaOH}$ was incubated overnight at $37^{\circ} \mathrm{C}$ to hydrolyse the RNA, cooled to $0^{\circ} \mathrm{C}$ and neutralized with $\mathrm{HCl}$; the DNA was precipitated with TCA (final TCA concentration $10 \%$ ). The precipitate was collected by filtration (Whatman GF/C), washed three times with $5 \%$ TCA, three times with ethanol and dried. All samples were counted in a Nuclear Chicago scintillation counter with toluene/2,5-diphenyloxazole (PPO)/1,4-di-2-(5-phenyloxazolyl)benzene (POPOP) scintillation mixture.

Extraction of ATP. The extraction technique was essentially as described by Gustafsson (1979). Frozen mycelium was ground with acid-washed sand for about $1 \mathrm{~min}$ in a cold mortar, then suspended in $1.2 \mathrm{ml}$

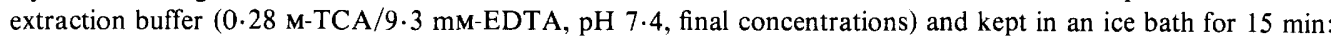
the supernatant was recovered by centrifugation. The pellet was extracted twice with $1 \mathrm{ml}$ extraction buffer. The TCA in the combined supernatant was removed by extraction with cold water-saturated ether which was, in turn, removed by bubbling $\mathrm{N}_{2}$. The insoluble material in the extract was removed by centrifugation. ATP was either estimated immediately or the extract was stored frozen for a maximum of $48 \mathrm{~h}$.

Luciferin-luciferase assay. The ATP in the extract was assayed according to the procedure of Lundin \& Thore (1975). Luminescence measurements were made in a Beckman liquid scintillation counter (model LS 250). For each series of assays a standard calibration curve was prepared using 1 to $10 \mathrm{nM}$-ATP in $2 \mathrm{ml}$ of $3 \mathrm{mM}-\mathrm{MgSO}_{4}$ in $100 \mathrm{~mm}$-glycylglycine buffer brought to $\mathrm{pH} 7.4$ with $\mathrm{KOH}$. Each vial, to which $100 \mu$ luciferase enzyme was added, was placed in the liquid scintillation counter and the count was taken after $10 \mathrm{~s}$.

Specific activity of ATP pools. The amount of ATP in a known volume of the sample was measured by the luciferase assay. To determine the activity of $\left[{ }^{3} \mathrm{H}\right]$ adenosine, $50 \mu \mathrm{l}$ extract was mixed with $20 \mu 1$ pure ATP $\left(1 \mathrm{mg} \mathrm{ml}^{-1}\right)$, spotted on thin-layer PEI-cellulose plates and chromatographed in one dimension with $1.2 \mathrm{M}-\mathrm{LiCl}$ (Randerath \& Randerath, 1967). The ATP spots were detected under an ultraviolet lamp, scraped and counted in toluene/PPO/POPOP scintillation mixture.

Isolation of native DNA from differentiating cultures. A 101 carboy containing 61 GCY medium was inoculated with mitospores at a concentration of $5 \times 10^{4} \mathrm{ml}^{-1}$ and grown with forced aeration for 20 to $24 \mathrm{~h}$ at $25^{\circ} \mathrm{C}$. The cells were filtered aseptically through nylon filters ( $75 \mu \mathrm{m}$ mesh diam.), washed with $51 \mathrm{DS}$ buffer, resuspended in a 51 carboy containing $21 \mathrm{DS}$ buffer and $10 \mu \mathrm{g}$ chloramphenicol $\mathrm{ml}^{-1}$ (to prevent bacterial contamination) and induced to differentiate by forced aeration. Samples of $250 \mathrm{ml}$ were taken, filtered on sterile Whatman filters, suspended in $50 \mathrm{ml}$ DS buffer containing $\left[{ }^{3} \mathrm{H}\right]$ adenosine $\left(0.5 \mu \mathrm{Ci} \mathrm{m} l^{-1} ; 18.5 \mathrm{kBq} \mathrm{ml}^{-1}\right)$ in $150 \mathrm{ml}$ Erlenmeyer flasks and labelled for $30 \mathrm{~min}$ as described above. Native DNA from these pulse-labelled cells was extracted and analysed in $\mathrm{CsCl}$ gradients according to Ojha \& Turian (1977). The individual fractions from the gradients were denatured, fixed on Millipore filters and hybridized with ${ }^{32} \mathrm{P}$-labelled rRNA to localize the rRNA cistrons (Ojha \& Turian, 1977).

Amounts of cistrons coding for rRNA in differentiating cells. Cells were grown, induced to differentiate and pulse-labelled as described above. Native DNA was isolated, denatured, fixed on Millipore filters and hybridized with ${ }^{32}$ P-labelled rRNA (Ojha \& Turian, 1977).

\section{RESULTS}

Developmental stages. Under our experimental conditions, timing of the morphogenetic sequence during the transition of the vegetative hyphal apex into asexual zoosporangia took place in the following stages: (I) cessation of apical elongation, 0 to $1 \mathrm{~h}$; (II) enlargement or swelling of the apex (club-like stage), 1 to $2 \mathrm{~h}$; (III) septum formation (differentiation of the terminal cell into a zoosporangium), 2 to $3 \mathrm{~h}$; (IV) maturation, papilla formation and zoospore discharge, 4 to $5 \mathrm{~h}$.

Growth and macromolecular biosynthesis. The transfer of plants from GCY medium to dilute mineral salt (DS) solution (the induction medium) resulted in a general slowing down of 


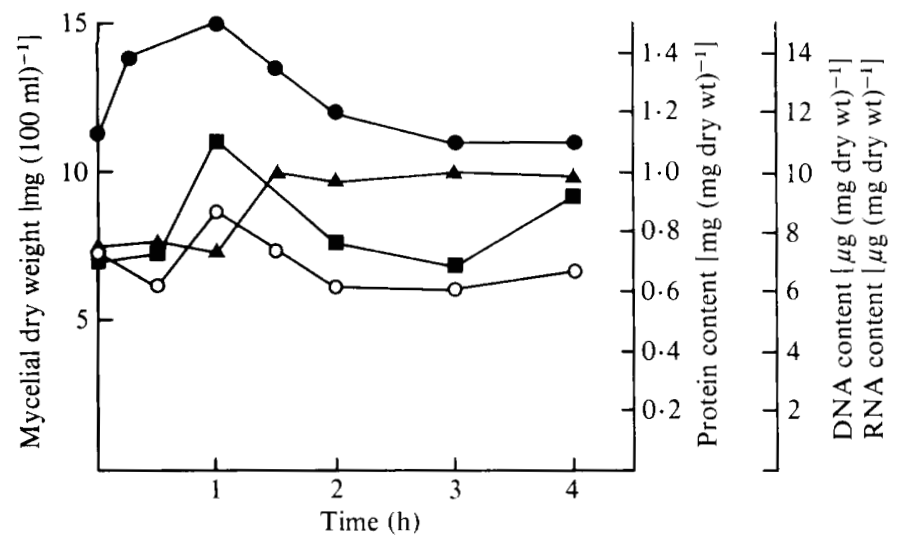

Fig. 1. Changes in mycelial dry weight $(\mathbf{\Delta})$, DNA ( $\mathbf{\square})$, RNA $(\boldsymbol{O})$ and protein $(\mathrm{O})$ during zoosporangial morphogenesis in Allomyces arbuscula. Samples were collected and processed as described in Methods.

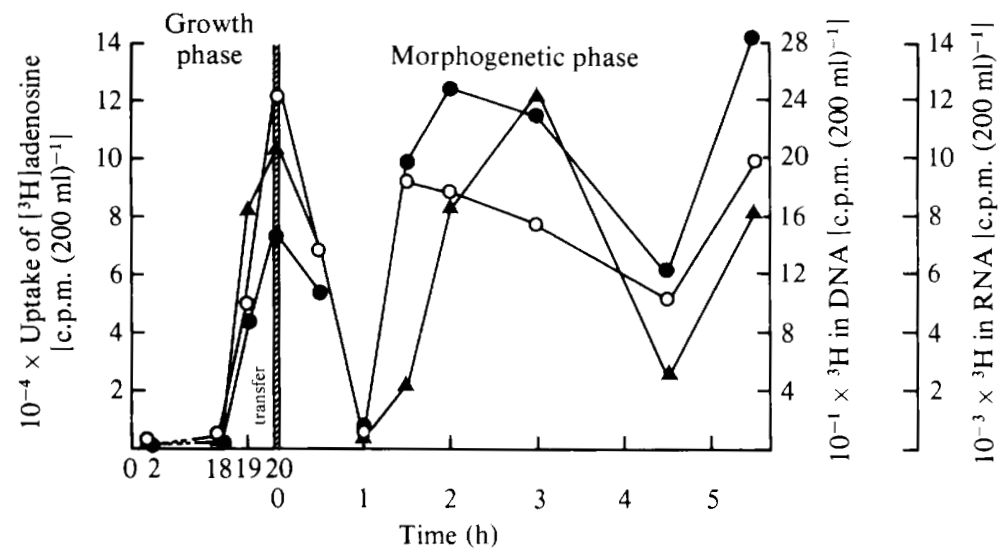

Fig. 2. Kinetics of uptake (O) of $\left[{ }^{3} \mathrm{H}\right]$ adenosine and its incorporation into RNA (O) and DNA (A) during the growth phase and zoosporangial morphogenesis.

macromolecular biosynthesis. The total cellular mass, DNA, RNA and protein continued to increase up to $1 \mathrm{~h}$ after transfer but, as differentiation progressed, their amounts decreased (Fig. 1), although they did not drop below the pre-transfer level. The amount of DNA synthesis, however, showed a second wave of stimulation coinciding with septum formation and zoosporangial maturation (Fig. 1). The initial increase in macromolecular components following transfer may be due to the balanced state of the metabolic pools of the cells at the time of transfer, which were adequate to support a little growth before depletion or reorientation in the metabolism suitable for differentiation set in. The increase in dry weight should reflect the synthesis of cell wall material required for zoosporangial development from the second hour of induction.

DNA synthesis during differentiation. Total uptake of $\left[{ }^{3} \mathrm{H}\right]$ adenosine and its incorporation into RNA and DNA during growth and the morphogenetic stages are shown in Fig. 2. Uptake and incorporation of the precursor into RNA and DNA increased linearly during the growth phase. Comparison of the synthetic process with the morphogenetic sequence revealed that stage $\mathrm{I}(0$ to $1 \mathrm{~h})$ was characterized by a progressive decline in uptake and in RNA and DNA synthesis. Stages II and III ( 1 to $3 \mathrm{~h}$ ) were paralleled by a stimulation in uptake and in RNA and DNA synthesis. However, RNA synthesis started to diminish 


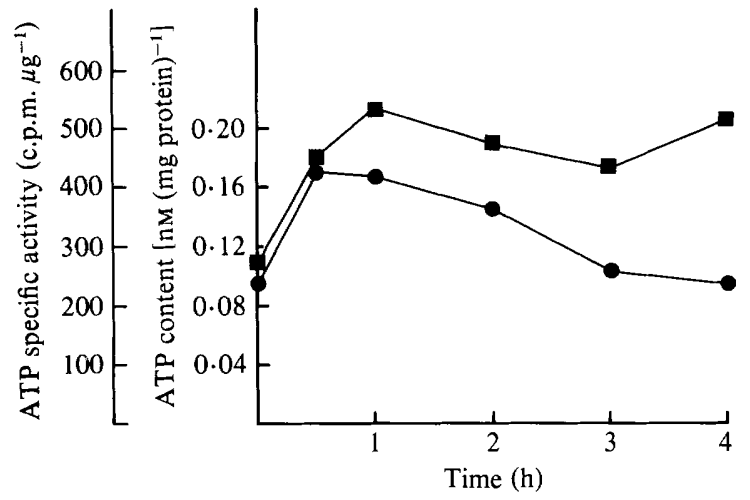

Fig. 3. Changes in ATP content during zoosporangial differentiation. Samples taken at intervals indicated were extracted and the ATP content ( $(\mathbf{)})$ and its specific activity ( $\square$ ) were measured as described in Methods.

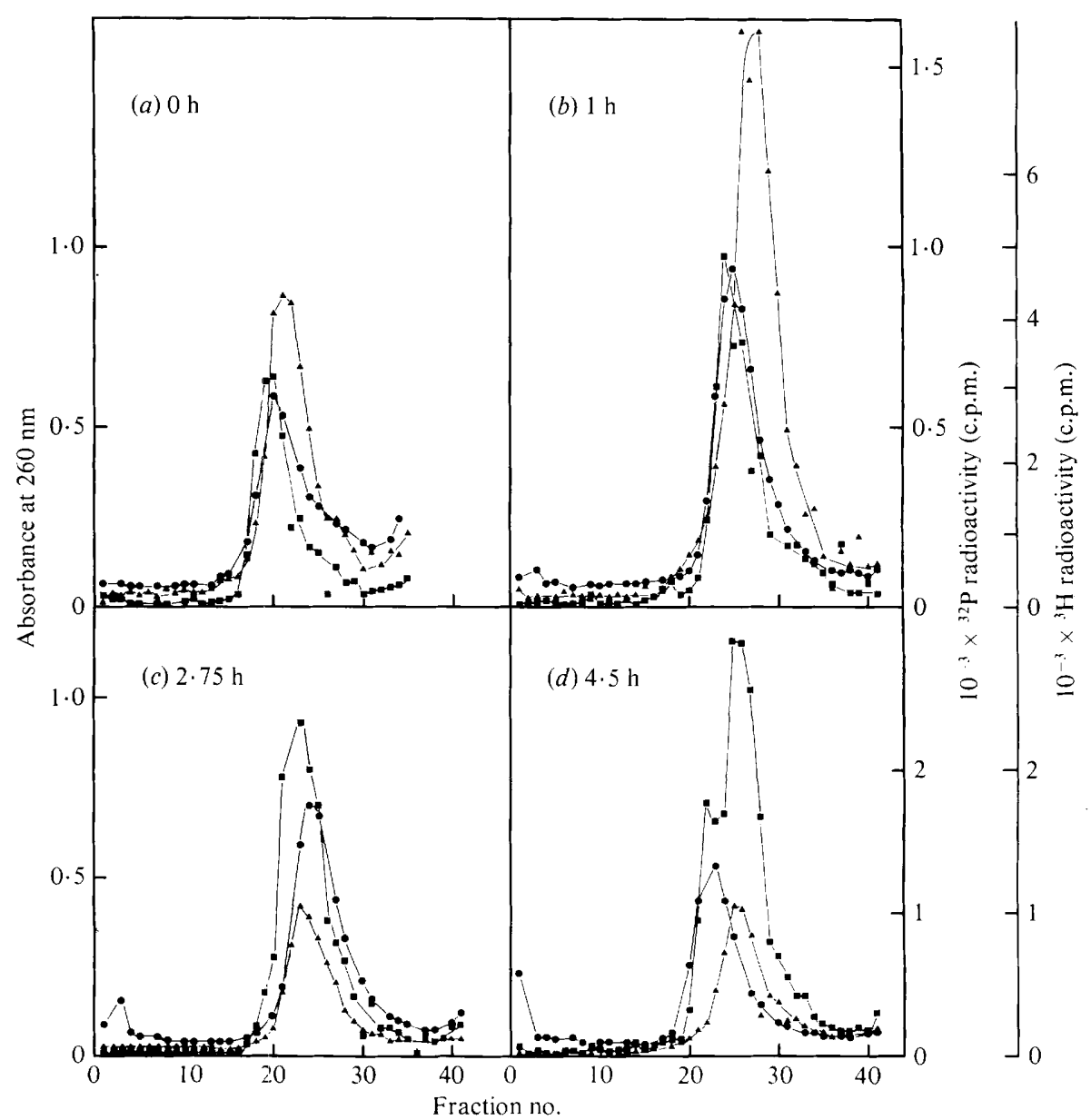

Fig. 4. Replication of rRNA cistrons during zoosporangial differentiation. Cultures were initiated as described in Methods. Cell samples taken at $0,1,2.75$ and $4.5 \mathrm{~h}$ were filtered, suspended in $50 \mathrm{ml}$ DS buffer containing $25 \mu \mathrm{Ci} \mid{ }^{3} \mathrm{H}$ |adenosine and labelled for $30 \mathrm{~min}$. The native DNA from the cell samples was extracted and the rRNA cistrons were resolved by fractionation of the labelled DNA on $\mathrm{CsCl}$ gradients and hybridization of each fraction with ${ }^{32} \mathrm{P}$-labelled homologous $25+18 \mathrm{~S}$ RRNA as described elsewhere (Ojha \& Turian, 1977). Absorbance at $260 \mathrm{~nm}(\mathbf{O}) ;{ }^{3} \mathrm{H}$ radioactivity $(\mathbf{\square}) ;{ }^{32} \mathrm{P}$ radioactivity $(\mathbf{\Delta})$. 


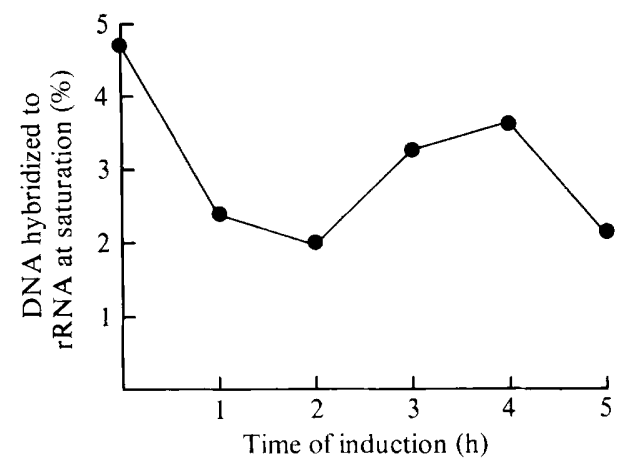

Fig. 5. Amount of rRNA cistrons during zoosporangial differentiation. Cultures were induced to differentiate as described in Methods. At intervals samples were taken and pulse-labelled in $50 \mathrm{ml}$ DS buffer containing $25 \mu \mathrm{Ci}\left[{ }^{3} \mathrm{H}\right.$ ]adenosine. The DNA was extracted, immobilized on Millipore filters and hybridized with homologous ${ }^{32} \mathrm{P}$-labelled rRNA under optimum conditions (Ojha \& Turian, 1977). The amount of DNA and its specific activity on each filter was: 0 h. $11.6 \mu \mathrm{g}, 280$ c.p.m. $\mu \mathrm{g}^{-1} ; 1 \mathrm{~h}, 18.4 \mu \mathrm{g}$, 180 c.p.m. $\mu \mathrm{g}^{-1} ; 2$ h, $21 \mu \mathrm{g}, 170$ c.p.m. $\mu \mathrm{g}^{-1} ; 3$ h, $7.2 \mu \mathrm{g}, 170$ c.p.m. $\mu \mathrm{g}^{-1} ; 4$ h, $3.4 \mu \mathrm{g}, 140$ c.p.m. $\mu \mathrm{g}^{-1}$; $5 \mathrm{~h}, 3 \mu \mathrm{g}, 70$ c.p.m. $\mu \mathrm{g}^{-1}$. The specific activity of ${ }^{32} \mathrm{P}$-labelled rRNA was 5268 c.p.m. $\mu \mathrm{g}^{-1}$.

rapidly after $1 \mathrm{~h} 30 \mathrm{~min}$ induction whilst uptake continued for a further $30 \mathrm{~min}$ more. The increase in DNA synthesis lagged, continued up to $3 \mathrm{~h}$ and then started to decrease.

When the pulse-labelling was done in spent differentiation medium, stimulation of DNA synthesis associated with $3 \mathrm{~h}$ induction (stage III) did not occur.

ATP content during differentiation. The transfer of an actively growing mycelium into the induction medium resulted in a rapid increase in ATP which continued to accumulate for up to $1 \mathrm{~h}$ and then started to decrease. The specific activity of the ATP pools followed the accumulation pattern, i.e. an increase up to $1 \mathrm{~h}$ followed by a gradual decrease (Fig. 3).

Synthesis of rDNA. The results of the analysis of newly synthesized native DNA on CsCl equilibrium density gradients and subsequent hybridization of individual fractions with homologous ${ }^{32} \mathrm{P}$-labelled rRNA to localize the ribosomal cistrons are shown in Fig. 4 . It is clear from the labelling pattern that up to fairly advanced stages of induction $(2.75 \mathrm{~h})$ all the DNA components continued to be synthesized at a uniform rate. However, at the stage of papilla formation and zoospore discharge (stage IV), preferential replication of the cistrons coding for rRNA occurred (Fig. $4 d$ ).

The amount of rRNA genes synthesized at different stages of development was estimated by rRNA-DNA hybridization of pulse-labelled DNA during differentiation. The results showed that the initial stages of development (reorganization of the hyphal apex) coincided with a decrease in the amount of rRNA cistrons, with a minimum at $2 \mathrm{~h}$. From this time to the fourth hour, while the zoosporangia were maturing with formation of their ribosomal nuclear caps, there was a marked increase in the synthesis of rRNA cistrons, to such an extent that the number of gene copies was finally roughly equal to that of the vegetative phase (Fig. 5).

\section{I S C U S S I ON}

As a consequence of starvation-associated morphogenesis, there is a redistribution of cytoplasm in the hyphal territory of young plants: an apical zone with dense, granulated cytoplasm, and a distal zone with highly vacuolated cytoplasm containing sparsely distributed nuclei (Hatch, 1935; Turian, 1957). Our results show that the rate of DNA synthesis fluctuates during such cytoplasmic reorganization associated with zoosporangial differentiation. The early developmental stages correspond to a decline in the rate of DNA synthesis, whereas the formation of apical septa to delimit the zoosporangial territories accompanies a renewal of synthetic activity of both DNA and RNA. This might answer the 
need for increased ribosomal content, further packed into zoosporic nuclear caps (Blondel \& Turian, 1960; Lovett, 1975).

Since the fluctuations in DNA synthesis correspond to the variations in $\left[{ }^{3} \mathrm{H}\right]$ adenosine uptake, it would appear that the labelling pattern reflects a change in the uptake of the precursor and therefore cannot be taken as a measure of the true DNA synthetic rate. In general, the rate of uptake of the precursor molecule does not exceed its utilization. So if the rate of uptake is low it would mean either that there is an expansion of the internal pool due to the catabolic reactions and turnover of the mRNA or a modification in the transport system due to the changes in the membrane system or enzymes linked with early steps in adenosine metabolism (Li \& Hochstadt, 1976).

The incorporation of nucleoside precursors into nucleic acids may be regulated at three levels: (1) transport of the precursors in the cell, (2) their incorporation into triphosphates and (3) the incorporation of triphosphates into nucleic acids. We have measured a decrease in the uptake of $\left[{ }^{3} \mathrm{H}\right]$ adenosine and its incorporation into DNA up to $1 \mathrm{~h}$ after transfer to the differentiation medium and a subsequent increase in uptake and DNA synthesis up to 2 and $3 \mathrm{~h}$, respectively (Fig. 2). However, the direct precursor of adenosine in nucleic acid, ATP, showed a considerable increase, which appeared to come from de novo synthesis and not from the degradation or turnover of mRNA, since the specific activity of the ATP pool continued to increase for up to $1 \mathrm{~h}$ post-transfer. Taking this fact into account, it would appear that whatever $\left[{ }^{3} \mathrm{H}\right]$ adenosine entered the cell was utilized for ATP synthesis. The decrease in uptake was probably related to other steps before the biosynthesis of ATP and therefore the decline in nucleic acid synthesis may not be due to constraints on the supply of the ATP precursor. A transient increase in ATP accumulation during growth on starvation, particularly for nitrogen source, and differentiation has also been reported for other micro-organisms (Dietzler et al., 1974; Maeba \& Shipman, 1978). The increase in uptake of $\left[{ }^{3} \mathrm{H}\right.$ ]adenosine and its incorporation into DNA after $1 \mathrm{~h}$ should indicate a more efficient flux through the ATP precursor. This increased DNA synthesis might reflect active mitosis associated with enlargement of the zoosporangia.

The $\mathrm{CsCl}$ equilibrium density gradient analysis of the newly synthesized DNA at various stages of induction (up to $2.75 \mathrm{~h}$ ) indicated uniform labelling of the DNA synthesized. At a later stage (zoosporangial discharge), however, preferential labelling of the rRNA cistrons took place (Fig. $4 d$ ). Since this occurs at the final stage of differentiation, it may not be associated with morphogenesis. It could be that by this time sufficient metabolites have accumulated in the medium to permit reinitiation of growth processes and that this impetus is translated by preferential labelling of rRNA cistrons. This assumption is reasonable since at this stage all biosynthetic parameters again show an increase (Figs 1 and 2). Our observation resembles that for starved Tetrahymena cells which when re-fed show a preferential labelling of their rRNA cistrons (Engberg et al., 1972).

We wish to thank Mrs A. Cattaneo for her excellent technical assistance.

\section{REFERENCES}

Blondel, B. \& Turian, G. (1960). Relation between basophilia and fine structure of cytoplasm in the fungus Allomyces macrogynus Em. Journal of Biophysical and Biochemical Cytology 7, 127-134.

Dietzler, D. N., Lais, C. J. \& Leckie, M. P. (1974). Simultaneous increase of the adenylate energy charge and the rate of glycogen synthesis in nitrogen starved Escherichia coli W $4597(\mathrm{k})$. Archives of Biochemistry and Biophysics 160, 14-25.

EMERSON, R. (1941). An experimental study of the life cycles and taxonomy of Allomyces. Lloydia $\mathbf{4}$, 77-144.

Engberg, J., Mowat, D. \& Pearlman, R. E. (1972). Preferential replication of ribosomal RNA genes during a nutritional shift-up in Tetrahymena pyriformis. Biochimica et biophysica acta 272, 312320.

Gustafsson, L. (1979). The ATP pool in relation to the production of glycerol and heat during growth of the halotolerant yeast Debaryomyces hansenii. Archives of Microbiology 120, 15-23.

Hatch, W. R. (1935). Gametogenesis in Allomyces arbuscula. Annals of Botany 49,623-649.

Howell, S. H. (1973). The isolation and analysis of DNA from eukaryotic cells. In Molecular Tech niques and Approaches in Developmental Biology, pp. 117-140. Edited by M. J. Chrispeels. New York: Wiley-Interscience. 
Li, C. \& Hochstadt, J. (1976). Transport mechanism in isolated plasma membranes. Nucleoside processing by membrane vesicles from mouse fibroblast cells grown in defined medium. Journal of Biological Chemistry 251, 1175-1180.

LOVETT, J. S. (1975). Growth and differentiation of the water mold Blastocladiella emersonii: cytodifferentiation and the role of ribonucleic acid and protein synthesis. Bacteriological Reviews 39. 345404.

Lundin, A. \& Thore, A. (1975). Comparison of methods of extraction of bacterial adenine nucleotides determined by firefly assay. Applied Microbiology 30, 713-721.

MACHLIS, L. (1953). Growth and nutrition of water molds in the sub-genus Allomyces. 1. Growth factor requirements. American Journal of Botany $\mathbf{4 0}$. 189-195.
Maeba, P. Y. \& Shipman, R. (1978). Incorporation of ${ }^{32} \mathrm{P}$ into nucleotides, polyphosphates and other acid soluble compounds by Myxococcus xanthus during myxospore formation. Journal of Bacteriology 136, 1058-1069.

OJHA, M. \& TuRian. G. (1971). Interspecific transformation and DNA characteristics in Allomyces. Molecular and General Genetics 112, 49-59.

OJHA. M. \& TURIAN, G. (1977). Ribosomal RNA cistrons in Allomyces arbuscula. Biochimica et biophysica acta 478, 392-406.

RANDERATH, K. \& Randerath, E. (1967). Thin layer separation methods for nucleic acid derivatives. Methods in Enzymology 12A, 323-347.

Turian, G. (1957). Recherches sur la morphogenèse sexuelle chez Allomyces. Bulletin de la Société botanique suisse 67, 458-486.

TURIAN. G. (1963). Synthèse différentielle d'acide ribonucléique et différenciation sexuelle chez l'Allomyces. Developmental Biology 6, 61-72. 